\title{
FRA BERLIN TIL BEIJING - Et essay om sport og politik
}

\author{
"At give Beijing mulighed for at afholde de olympiske lege vil fremme \\ udviklingen på menneskerettighedsområdet"
} (Liu Jingmin, vicepræsident for Beijings Olympiske Komités kandidatur, april 2001)

Kina har gennem de sidste årtier gennemlevet en omfattende udviklingsproces, hvorved hen ved 300 millioner mennesker er blevet løftet ind i middelklassen, og Kina er blevet en motor i verdensøkonomien. Samtidig har Kina i dag bevæget sig langt $\mathrm{i}$ forhold til maoismens totale retslige vilkårlighed, massehenrettelser af kontrarevolutionære, hungersnød udløst af en katastrofal landbrugspolitik samt omfattende ødelæggelser af uerstattelige kulturværdier I dette essay vil jeg med sporten som udgangspunkt argumentere for, at Kinas ubestridelige fremskridt ikke skal få os til at vende det blinde øje til det faktum, at regimet stadig fundamentalt set bygger på det gamle kommunistpartis magtmekanismer blot i moderniseret form. På trods af lokale eksperimenter med former af demokrati og en på papiret bekenden sig til menneskerettigheder satser Kina satser fortsat på modernisering - forstået som økonomisk vækst og teknologiske fremskridt, men ikke på modernitet - forstået som udviklingen af et dialogisk og åbent civilsamfund med hånd $i$ hanke med den politiske ledelse. Det maner til eftertanke, at både Det

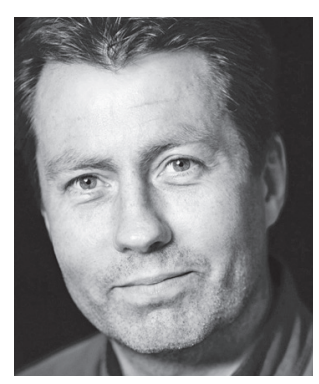

AF

HANS BONDE

tredje Rige og Sovjetkommunismen viste sig at være langt værre end frygtet, da disse autoritære samfundssystemer brød sammen, og det endelig var muligt at få en mere ucensureret adgang til, hvad der var foregået med hensyn til arbejdslejre, forfølgelse af de af regimet definerede politiske modstandere og totalitær kontrol med befolkningen helt nede på hverdagsplanet. I det følgende vil kronprins Frederiks kandidatur til Den Internationale Olympiske Komité (IOC) blive diskuteret $\mathrm{i}$ lyset af et tidligere dansk royalt medlem af IOC, prins Axel. Dernæst vil prote- 
sterne frem mod OL i Beijing og Kinas modsvar blive diskuteret i sammenhæng med den kinesiske sportspolitik og tidligere tendenser til at blande sport og politik. Endelig vil åbningsceremonien ved OL i Beijing blive analyseret i relation til åbningsceremoniernes generelle funktion som kulturpropaganda for værtslandet.

\section{PRINSER OG POLITIK}

Diskussionen om kronprins Frederiks opstilling til Den Internationale Olympiske Komité ved IOC's session i København 2009 tager udgangspunkt i det epokegørende i, at et medlem af kongehuset for første gang bliver involveret $\mathrm{i}$ forholdet mellem sport og politik.

Hermed overses det, at den danske kongefamilie før har været indblandet i sportspolitik, og at IOC før har haft en dansk prins som repræsentant for Danmark, nemlig fra 1932 til 1959 Christian X's fætter, prins Axel.

Prinsen var kontreadmiral og en bredt respekteret direktør i ØK. Han brandede sig i høj grad gennem sport af mere aristokratisk tilsnit som pioner inden for flyvning, præsident for Kgl. Dansk Automobil Klub i årene 1920 til 1938 samt æresmedlem af Kjøbenhavns Amatør Sejlklub. Ligesom det var et totalitært regime - den kinesiske étpartistat - der med OL i Beijing spøgte i kulissen for prins Frederik - var det for prins Axel de nazistiske lege i 1936, der dannede baggrunden for hans sportspolitiske ilddåb.

\section{OL I BERLIN 1936}

De olympiske lege i 1936 var den enkeltbegivenhed, der bragte danskerne tættest på nazisternes satsning på organisation og orden og forsøget på at skabe stærke fællesoplevelser gennem æstetiske masseoptrin.

I Danmark var der bred interesse for, at legene nu for første gang siden OL i Stockholm i
1912 for alvor var kommet tæt på, skønt man i Danmark udmærket kendte til det nazistiske regimes jødehad, koncentrationslejre og ensretning blandt andet af sporten.

I Danmark udviklede der sig en protestbevægelse blandt kulturradikale kunstnere, der forsøgte at etablere en boykot mod konkurrencen om sportskunstværker ved OL. Som dansk IOCmedlem rykkede prins Axel ud ved at indhente et svar fra præsidenten for Den Tyske Olympiske Komité, Dr. Theodor Lewald, der garanterede for, at der var fri adgang til at deltage i konkurrencen for alle kunstnere uanset religiøst eller racemæssigt tilhørsforhold. Svaret overbeviste dog ikke de aktionerende kunstnere, som var mere optaget af den generelle tyske jødepolitik, som blandt andet førte til, at Tyskland i stort tal undgik at udtage jødiske idrætsudøvere til OL-truppen.

Den Danske Olympiske Komité (DOK), hvortil prins Axel var født medlem, afviste, at Berlinlegene ville blive brugt til politisering. Som modsvar mod "kunstnerprotesten«, der blev set som utidig indblanding i idrættens forhold, svarede DOK i punktform, at "Betegnelsen 'Hitlerolympiade' er misvisende og tendentiøs. Legene er af Den Internationale Olympiske Komité henlagt til Tyskland, men de tyske arrangører har i enhver henseende den pligt at holde sig legenes regler og ånd efterrettelig og har givet de mest vidtgående løfter herom ... Mellem dansk og tysk idræt består et fast og venskabeligt samarbejde, som Danmarks idrætsmænd er glade for. Vi har regelmæssige idrætskampe i mange idrætsgrene, i fodbold, roning, lawn-tennis, brydning, boksning, atletik, ridning, svømning osv. osv. Eftersom vi kun har udbytte og glæde af dette samkvem med Tyskland, ville det være komplet meningsløst at holde os borte fra et verdensstævne, fordi det finder sted i Tyskland, 
hvor vi altid føler os velkomne, og også denne gang er sikker på at blive behandlet godt ... Skal der fra dansk side protesteres mod visse tyske metoder inden for landets egne grænser, skulle idrætsmændene, der kun har mødt venlighed fra tysk side, være de sidste til at fremkomme med en sådan protest «.

Der kan ikke efterfølgende spores nogen kritik af Berlin-legene fra Danmarks Olympiske Komité eller fra det danske medlem af IOC, prins Axel. I det hele taget viste det sig, at IOC fandt det meget nemmere at samarbejde med diktaturer, der kanaliserede store ressourcer over i eliteidrætten, end med vestlige demokratier, der betragtede idræt som et udmærket kulturfænomen, men uden større statslige satsninger.

IOC's holdning viste sig ved tildelingen af Sommer-OL i 1940 til Tokyo og Vinter-OL til Sapporo til trods for, at Japan i 1931 havde annekteret Manchuriet og siden 1910 havde besat Korea. OL 1944 blev imidlertid tildelt London, hvilket dog først blev en realitet i 1948. IOC's gode samarbejde med det nazistiske styre viste sig klart, da den reagerede på aflysningen af Vinter-OL i Sapporo ved få måneder efter de antijødiske overgreb under Krystalnatten 9. november 1938 at tildele vinterlegene i 1940 Tysklands fineste vintersportssted Garmisch Partenkirchen, der også havde stået for VM i 1934 og 1938 samt OL i 1936.

Også i tiden efter de olympiske lege blev budskabet om den vitale og sportsglade nation udbredt. Det foregik gennem Leni Riefenstahls æstetiske og teknisk nyskabende filmværk Olympia om Berlinlegene, der havde premiere i Tyskland i 1938 på Førerens fødselsdag. Her blev der udbredt et effektivt propagandabudskab om Tyskland som en fredsskabende nation med accept af den olympiske multikulturalisme og med Hitler som en landsfader, der fremstod menneskelig og engageret i den moderne konkurrencesport, som han dybest set foragtede, fordi den i princippet gav alle racer lige adgang til at vinde.

Når IOC traditionelt har arbejdet så godt sammen med et-partistater, kan det skyldes, at IOC også selv fungerer som en selvsupplerende komité, hvor magtudøvelsen foregår fra top til bund eller med det tidligere IOC-medlem Kai Holms ærlige ord i anledning af, at IOC-kongressen kommer til København i 2009 (Politiken 12/1, 2009: "Normalt er det, hvis jeg skal være helt ærlig, eksekutivkomiteen, der tager alle afgørelser, men jeg må sige, at vi helt afgjort har mere at sige, end vi haft i meget lang tid... Mest på det praktiske område. For selve det intellektuelle indhold, styres stramt fra præsidenten selv, så der er ikke meget indflydelse (Heinskou, 2009)).

\section{KONGEFAMILIEN OG SPORTEN}

Den danske kong Christian $\mathrm{X}$ var til stede ved filmpremieren i København. I anledning af premieren skrev den konservative avis Berlingske Tidende, at: "Det er stort og herligt at have været med til disse uger, da alverdens idræt holdt mønstring og uden mislyd kæmpede for idrættens højeste ære ... »Der Führer « har været et af de taknemmeligste kameraobjekter, og man kommer meget tæt ind på hans loge i øjeblikke, der afslører hans intense spænding, hans nervøsitet, hans hjerteangst - da han uafbrudt gnider sine knæ - og hans gåen op i landsmændenes kamp for førstepladserne. Så intimt filmes sjældent en diktator .

Under den tyske besættelse af Danmark spillede prins Axel i øvrigt en politisk rolle, idet den såkaldte Højgaardkreds efter 9. april 1940 søgte at få kongen til at støtte kredsens planer om indsættelse af en »upolitisk « regering ledet af prinsen. Højgaardkreden krævede, at "stats- 
autoriteten ... i langt højere grad end hidtil“ blev »et bestemmende princip i det politiske liv«. Kredsen havde dog udspillet sin rolle allerede inden udgangen af 1940 , da Christian X havde fastholdt de parlamentariske grundprincipper over for kredsens ønsker.

Under besættelsen var kongefamiliens opbakning til idrætten i øvrigt med til at give idrætsbevægelsen anerkendelse fra højeste sted. Kongens tilstedeværelse ved sportskampe var med til at styrke alsangsstemningens nationalfølelse.

Heldigvis undgik kongen at skulle tage stilling til, om han ville hilse på besættelsesmagtens soldater ved landskampe. Fodboldlandskampen mod Tyskland 30. juni 1941 i Parken blev aflyst på grund f. antityske uroligheder ved en foregående kamp. Det må have løst et dilemma. Normalt viste kongen tyskerne korrekt og værdig optræden, men heller ikke mere, hvilket som bekendt senere førte til omfattende politiske problemer under "telegramkrisen" i 1942, hvor kongen lapidarisk takkede Hitler for hans lykønskning i anledning af kongens fødselsdag 26. september, hvilket udløste et sandt raserianfald hos den tyske fører. Aflysningen af landskampen betød, at kongen undgik at skulle beslutte sig for, om han ville træde ned på grønsværen i halvlegen og - som den svenske konge havde gjort det 5. oktober 1941 - hilse på de tyske spillere, der heilede før og efter kampen. Gjorde Christian X ikke det, ville det givetvis blive udlagt som en politisk manifestation mod besættelsesmagten, ikke mindst fordi han havde for vane at hilse på de svenske spillere ved landskampe.

\section{KRONPRINS FREDERIK}

Igen $\mathrm{i}$ dag er en dansk prins bragt i stilling som IOC-medlem. På IOC-kongressen ved OL i Torino februar 2006 var det den forhenværende
DIF-formand Kai Holms mål at få den prestigefyldte IOC-kongres til København i 2009, hvor hensigten er, at kronprins Frederik skal indvælges i IOC. Det var en vanskelig opgave, da det foregik midt under Muhammed-krisen, men Kai Holm udtrykte i sin tale efter at have fået grønt lys fra regeringsniveauet sin personlige afstandtagen fra Muhammed-tegningerne, og København blev valgt som værtsby.

Det er aldrig neutralt at skulle møde et land, hvor idrætten er tildelt en central politisk rolle. Det er derfor vigtigt, at idrætslederne og kronprinsen er bevidste om de politiske implikationer, som også er en del af den sportslige aktivitet, så atleter, trænere og ledere kan undgå at blive brikker i et politisk spil. Prins Axel kan bruges som et manende eksempel på, hvordan også royale idrætsledere meget nemt kommer til at medvirke til regimers selviscenesættelse. Det er klart, at DIF får utrolig god branding ud af kronprinsens kandidatur, men mindre soleklart, om kongehuset ikke mister noget af sin integritet og sin hæven sig over de politiske vande ved at stikke hånden ind i den idrætspolitiske hvepserede.

For den danske kronprins, der kandiderer til den internationale olympiske komité er et af de store problemer, at han i tilfælde af at blive valgt skal sværge en olympisk ed om absolut loyalitet over for IOC, hvorfor han risikerer at komme i modstrid med den danske regering, hvilket ville være en bombe under monarkiet. Der har to gange før været en fundamental uenighed mellem IOC og den danske regering. Den første gang var i 1998/99, da den danske regering pressede på for oprettelsen af et uafhængigt dopingagentur (WADA) mod IOC's vilje. Den anden gang var fra 2000 - 2004, da IOC iværksatte et massivt pres for at indføje en artikel i EU's traktatgrundlag, der skulle undtage 
sporten fra reglerne om arbejdskraftens frie bevægelighed - en særregel den danske regering var meget imod

Den hollandske kronprins Willem-Alexander kom også ud i en politisk storm, da han personligt blev inviteret ind i IOC af den magtfulde præsident - Francos tidligere sportsminister Juan Antonio Samaranch. Willem-Alexander var smart nok til at opstille til IOC på et politisk set mindre turbulent tidspunkt i 1999, hvor 10 korrupte medlemmer af IOC netop var blevet smidt ud. Som kronprins har Willem-Alexander dog klare bånd på, hvor meget indflydelse han kan opnå i IOC, og i 2000 måtte han således til stor lettelse for den daværende premierminister træde ud af den magtfulde og omstridte udvælgelseskommission, der står for valget af OLværtsby.

Der var god grund til, at de danske idrætsledere og kronprinsen havde gjort sig sportens politiske karakter klart, inden de tog til Riget i Midten. Den Internationale Olympiske Komité og Danmarks Idræts-Forbund har gjorde dog meget lidt ud af at tage en offentlig debat om det politiske ved at deltage i OL i Kina, skønt den forhenværende DIF-formand Kai Holm erkendte, at deltagelsen var politisk, hvilket i øvrigt fik Jyllands-Posten til at spørge, hvordan kronprins Frederik så skulle kunne holde sig uden for politik.

Ved Salt Lake City-legene i 2002 benyttede præsident George Bush OL til den mest markante politisering i nyere tid. End ikke Hitler vovede at ændre ordlyden ved statsoverhovedets åbning af OL, men Bush talte på baggrund af terrorangrebet 11 . september 2001 helt uden for det faste oplæg om USA som en "stolt og beslutsom nation «. Samtidig var der ved åbningsceremonien indmarch af amerikanske politibetjente og brandmænd fra indsatsen i World Trade Cen- ter, som bar et sønderrevet og delvist brændt amerikansk flag, der angiveligt var fundet i ruinerne efter angrebet. Det kan derfor ikke undre, hvis den kinesiske regering fik det indtryk, at det var legitimt at bruge OL til egne politiske formål.

På den baggrund kan der spørges, om ikke Danmarks Idræts-Forbund og kronprins Frederik, der i Beijing besøgte den kinesiske statsleder $\mathrm{Hu}$ Jintao, lod sig forføre af en nation, der bruger sporten som kulisse for regimets selviscenesættelse? Har vi intet lært siden Berlin 1936?

\section{FACADEBYGGERI?}

Da Den Internationale Olympiske Komité i 1997 skulle besigtige Beijing med henblik på et værtskab for OL, var græsset langs køreturen ind til Beijings centrum malet grønt, smoggen renset af hovedstadens regeringsbygninger og jublende menneskeskarer med olympiske flag opstillet langs ruten. Kinas statsledelse opererede med at bruge kemiske midler for at sørge for godt vejr under OL, ligesom den evige tunge smog over Beijing blev reduceret via begrænsninger på trafikos og fabriksrøg. Beijings indbyggere blev trænet i at ophøre med at spytte, harke og mase i de hyppige køer, mens OL stod på. Pengesedler med Mao på udskiftedes til fordel for et OL-motiv, og der blev ikke serveret hundekød i den periode, hvor de udenlandske tilrejsende var til stede.

Var dette olympiske facadebyggeri et sindbillede på et styre, der ønskede at udrydde alle knaster og fremstille sig selv som pletfrit med brug af alle midler over for dem, som spolerer glansbilledet? I hvert fald erklærede de kinesiske autoriteter, at OL skulle foregå i harmoniens ånd, hvilket i praksis betyder uden disharmonier fra splittelsesmagere, dissidenter og separatister, læs: Tibetanere. 


\section{DEN TIBETANSKE MASKOT}

De kinesiske myndigheders fremfærd over for den tibetanske olympisk timede opstand med kampvogne og i tusindvis af paramilitære politifolk og riffelbevæbnede soldater fra "Folkets befrielseshær« skabte heller ikke ligefrem billedet af en fredelig nation, der reagerer dialogisk på markeringerne på 49-års dagen for det mislykkede tibetanske oprør i 1959, som kulminerede med Dalai Lamas flugt til Indien.

Når tibetanerne gik til angreb på kinesere ved det tibetanske religiøse og kulturelle centrum Lhasa, skyldes det ud over den generelle undertrykkelse af deres kultur også den kinesiske regerings politik med at lade den absolutte etniske majoritet i Kina, han-kineserne, strømme til Tibet for i sidste ende at udgøre en majoritet det besatte område. Kineserne er ikke til sinds at slippe den råstofrige region, der udgør en tiendedel af Kinas areal, med fare for, at andre urolige provinser som det muslimske Xinjiang lader sig inspirere.

Før og under OL blev medierne og internettet fortsat udsat for censur, og under urolighederne i Tibet blev alle internetforbindelser fra og til Tibet lukket ned og alle udlændinge fjernet, så udefrakommende øjenvidneskildringer var umulige. Samtidig blev de udenlandske tv-kanalers indslag om Tibet censureret bort af de kinesiske myndigheder. En ting er, at kapitalinteresser $\mathrm{i}$ de vestlige lande stiltiende accepterer undertrykkelsen i Kina, en anden ting er, at internetudbydere som Yahoo aktivt har hjulpet de kinesiske myndigheder med at opspore dissidenter via deres spor på internettet.

Én af de fem olympiske maskotter var i øvrigt den tibetanske antilope, et udryddelsestruet dyr, der mere end noget andet symboliser den spinkle og skrøbelige tibetanske identitet.
For at protestere mod krænkelser af menneskerettighederne - og især overgrebene mod de religiøse Falun Gong-udøvere - blev der tændt en "olympisk fakkel for menneskerettighederne i Kina« 9. august i Athen i Grækenland.

Det fromme, men urealistiske håb var naturligvis, at faklen i sidste ende skulle lande i Beijing. Det gjorde den så ikke, men til gengæld nåede denne alternative fakkel viden om inklusive til Kongens Nytorv i København i oktober 2007.

Der foregik altså ved OL i Beijing en kamp om de olympiske symboler. De kinesiske magthavere ønskede også, at den olympiske fakkel skulle bæres via en indenrigsrute over Taiwan, hvilket den taiwanske regering dog afviste, da den så det som et forsøg på symbolsk at indlemme østaten i Kina.

\section{HISTORISK SAMMENBLANDING AF SPORT OG POLITIK}

At Kina i høj grad lægger vægt på sportens politiske signalværdi, oplevedes på dansk grund, da der blev afholdt en sportsligt set uvæsentlig, men politisk set vigtig kamp mellem Tibet og Grønland i 2001. Det kinesiske udenrigsministerium var så vrede over, at pro-tibetanske kræfter fremstillede kampen som en "landskamp«, og at Tibet gennem flagning og andre nationale symboler sportsligt set ville blive anerkendt som nationalstat, at de truede de grønlandske myndigheder med, at det kunne gå ud over den store grønlandske rejeeksport til Kina.

Kina har før høstet gode erfaringer med at bruge sporten politisk. Faktisk er Kina én af de mest politiserende nationer i OL's historie i forsøget på at holde Taiwan ude gennem bål, brand og boykot. I 1971 søgte formand Mao at tilnærme sig den tidligere ellers så kapitalistiske og imperialistiske hovedfjende USA på grund af et 
voksende modsætningsforhold til Sovjetunionen. Murbrækkeren var bordtennis, og i april 1971 skete der et tøbrud mellem de to stater, da det amerikanske bordtennislandshold kom til Beijing.

Dette "ping-pong-diplomati « åbnede op for, at præsident Nixon i februar 1972 kunne møde formand Mao i den kinesiske hovedstad, efter at Kina allerede i oktober 1971 havde generobret sit sæde i FN. Den kinesiske sportsminister fra 1989 til 2000, Wu Shaozu, skrev senere, at: "kineserne har lært af ping-pong-diplomatiet, at sport og politik er uadskilleligt ... Sportsfolkene har påtaget sig et stort ansvar. De er vores politiske ambassadører«.

For den kinesiske statsledelse var formålet med de olympiske lege en ansigtsløftning, der demonstrerede - ikke mindst over for Kinas egen befolkning - at Kina nu endegyldigt var blevet en moderne superstat - også symboliseret ved medlemskabet af World Trade Organisation (WTO) i 2001.

For kineserne er sportens vigtigste funktion at tjene statens interesser, og det kan derfor ikke undre, at kineserne kører talentudviklingsprogrammer med muskelbiopsier på femårige, tæsk som pædagogisk værktøj, håndplukning af talenter til idrætsgrene ikke ud fra deres egne interesser, men ud fra fysiologiske parametre, hårdhændet frasortering af atleter, der er blevet skadet af den rigide træning, samt undertiden brug af ulovlige midler, som da kinesisk svømning blev ramt af en stor dopingskandale i 1990'erne.

\section{DET KINESISKE SPORTSSYSTEM}

I Kina er breddeidrættens vigtigste rolle at være udklækningssted for eliten, og eliten vil i reglen sige den olympiske elite, for Kina satser benhårdt på de olympiske discipliner, der er flest medaljer i, og dem, som det er nemmest at vinde i. Et klubsystem, som vi kender det i Danmark, hvor børnene melder sig ud fra egne interesser og skifter rundt, kendes stort set ikke. Gennem denne ensretning af sporten til at tjene olympiske mål er det lykkedes for kineserne at rykke fra at være nr. fire, til nr. tre og nr. to i nationskonkurrencen ved de seneste tre olympiske lege, og i Beijing lykkedes det endelig at markere sig som en af de to førende supermagter ved at blive nr. 1 foran USA målt på antal guldmedaljer - en status, der på det økonomiske område er blevet understreget kraftigt gennem den igangværende finanskrise. Faktisk gav denne rivalisering mellem Kina og USA OL i 2008 en aura af systemernes kamp som i koldkrigsdagene, hvilket yderligere øgede spændingen. For at kunne brillere i denne kamp har kineserne kastet 40 milliarder dollar efter OL.

Det gamle trygge elitesportssystem i Kina er i dag under ombrydning. Der tildeles ikke længere jobs efter karrierestop, og forældrene skal nu betale for at have børn og unge på sportsskolerne. En meget stor del af Kinas mange sportspensionister er ramt af skader og lever et liv i fattigdom uden mulighed for at få arbejde på grund af manglende skolekundskaber. Som et markant eksempel så maratonløberen Ai Dongmei sig nødsaget til at sælge sine medaljer for at kunne brødføde sin familie. Der er dog nu forsøg på at genintroducere princippet om, at staten har et ansvar for eliteidrætsfolkenes beskæftigelse efter karrieren.

I en totalitær stat som Kina er der ingen forestillinger om sportens autonomi og ej heller om fair play, der heller ikke har en pendant i det kinesiske sprog. Det nærmeste, man kan komme, er »mianzi«, der betyder at bevare sit ansigt 
eller sin ære og peger på, at det ikke er processen, men resultatet, der er det altafgørende. At tabe en international kamp vil i langt højere grad kunne føles som et vanærende svigt i en kinesisk end i en dansk kontekst.

Når Kina aldrig for alvor er blevet en stormagt inden for fodbolden, kan det meget vel være på grund af den udbredte match-fixing i den kinesiske liga såvel som i andre dele af sydøstasiatisk fodbold. Fodboldeksperter hævder, at en meget stor procentdel af alle kampes resultater i de sidste to år i den kinesiske liga har været aftalt på foranledning af spillesyndikater.

At kineserne kan have det svært med begrebet fair play, illustreres af, at det danske kvindelandshold ved VM i kvindefodbold 2007 i Kina blev aflyttet under et taktikmøde af to kinesere med kamera, der blev opdaget bag en spejlvæg, da det danske landshold holdt det sidste taktikmøde før 2-3-nederlaget til Kina. Er det et eksempel på den overvågning og spionage, som de udenlandske deltagere blev udsat for under OL?

Den kinesiske sportspolitik bygger ikke på individuel selvrealisering, men tværtimod på statslig profilering. Dette er senest blevet bekræftet ved, at den kinesiske landstræner i badminton, Li Yongbo, i juli 2008 har tilstået match fixing ved at have bedt en spiller om at tabe til en landsmand under OL i Athen i 2004. Uden blusel fastholder han at ville fortsætte med denne efter alt at dømme udbredte og for kineserne helt ukontroversielle praksis. På trods af denne sag og andre mærkværdige kampe mellem kinesiske spillere griber IOC ikke ind over for træneren, der derfor også opererede uden problemer under OL i Beijing. En ting er, at modstanderne herved snydes, en anden ting er, at store internationale resultater kan være helt afgørende for, at kinesiske topatleter tjener nok til at undgå at havne blandt det store proletariat af skadede og fattige pensionerede atleter uden nok boglig uddannelse til at kunne gøre sig på jobmarkedet. Det kan derfor være fatalt for en atlet at blive håndplukket til at tabe for at støtte nationens overordnede interesser.

\section{OL OG MENNESKERETTIGHEDERNE?}

Under OL lykkedes det for den kinesiske partiledelse at neddæmpe opmærksomheden omkring problemer med menneskerettighederne, behandling af politiske fanger, nedkæmpelsen af oprøret i Tibet og samarbejdet med dubiøse politiske regimer i den tredje verden såsom Burma, Nordkorea, Zimbabwe og ikke mindst Darfur i det vestlige Sudan, hvor kineserne til gengæld for lukrative energiinvesteringer og olieleverancer vender det blinde øje til muslimske regeringsstøttede militsers etniske udrensning af den sorte ikke-arabiske befolkning, der foreløbig har resulteret i mindst 200.000 døde.

Ytringsfriheden blev faktisk indskrænket frem mod og under OL. Som blot en blandt mange kan nævnes arbejder- og bondeaktivisten Yang Chunlin fra Kinas nordlige Heilongjiangprovins, der i sommeren 2007 indsamlede underskrifter til et åbent brev under overskriften "Vi vil have menneskerettigheder, ikke olympiske lege«. Myndighederne kvitterede ved at anholde ham, og i februar 2008 blev han iført lænker på hænder og fødder fremstillet i retten på grund af »statsundergravende virksomhed «.

Fra Danmarks Idræts-Forbunds og Den Internationale Olympiske Komités side forlød det, at OL vil medføre en forbedring af situationen på menneskerettighedsområdet i Kina, uden at der dog kunne registreres noget pres fra den olympiske bevægelses side.

Hvor vanskeligt det er at manøvrere i de olympiske skær, ses i øvrigt klart af, at bestyrelsesformanden for den danske organisation til støtte 
af eliteidræt Team Danmark blev udsat for kritik, da han i Team Danmarks blad Puls i december 2007 skrev: "Lad os slå det fast, at det ikke er atleternes opgave at forholde sig til politiske spørgsmål«, hvilket nemt kunne læses som en appel til atleterne om ikke at bruge deres ytringsfrihed, hvilket de da heller ikke gjorde i en grad, der på nogen måde kunne bringe dem på konfliktkurs med det kinesiske styre.

For at undgå, at atleterne skaber problemer med deres åbenmundethed, har den britiske olympiske komité (BOA) fået de britiske OL-deltagere til at underskrive en erklæring om, at de ikke vil snakke om politiske emner i relation til OL. Også i Belgien og New Zealand har der været forsøg på at give atleterne mundkurv på.

En vis begrænsning af den individuelle politiske propaganda ved OL er dog nok et gode, for den kan jo også bruges til det modsatte af en kamp for menneskerettigheder og nationernes selvbestemmelsesret. Eksempler er italienske fodboldspillere som Lazios Paolo di Canio, der har givet fascisthilsen ud mod de højreradikale tilskuere, de såkaldte ultras, og Juventus-målmanden Buffon, der på et tidspunkt valgte nummeret 88 på sin trøje, hvilket som bekendt udgør bogstavet H x 2 (Heil Hitler). Et af de seneste eksempler er den serbiske guldmedaljevinder Milorad Cavic, der blev udvist fra Europamesterskaberne i svømning i Eindhoven i marts 2008, da han ved sejrsceremonien bar en T-shirt med sloganet "Kosova er serbisk «.

Det er i øvrigt iøjnefaldende, at det danske brydeforbund i anledning af VM i 2009 i Herning har planlagt flere imødekommende tiltag over for deltagere fra Mellemøsten, hvor brydning i mange lande er en populær sport. "Den muslimske verden skal have et andet og mere positivt billede af Danmark, siger presse- og marketingansvarlig Mads Bang Aaen.« Yderst sympatisk, men burde DIF ikke reflektere over denne åbenlyst politiske gestus, der jo ikke just adskiller sport og politik?

Flere af de danske OL-deltagere ønskede dog at bruge deres ytringsfrihed. Tre af Danmarks olympiske roere i Beijing, Juliane Elander Rasmussen, Rasmus Quist og Mads Rasmussen hvoraf de sidste to af DIF blev kåret som "Årets Sportsnavn 2007 « - argumenterede for, at de anser det for deres pligt at ytre sig kritisk om forholdene i Kina i forbindelse med, at de den 13. december 2007 sammen med 95 kajakroere deltog i et sejlende fakkeltog i Københavns Havn, som Amnesty International var medarrangør af.

De tidligere stjerner, svømmeren Louise Ørnstedt, cykelrytteren Rolf Sørensen og håndboldspilleren Rikke Hørlykke, aftalte med Amnesty International, at de skal hjælpe organisationen med at sætte spotlys på menneskerettigheder i Kina frem mod OL.

Endelig startede den danske billedhugger Jens Galschiøt en kampagne "Farven orange«, der opfordrede folk fra hele verden til under OL at iføre sig orange tøj som en tavs protest mod Kinas krænkelser af menneskerettighederne, hvilket dog ikke fik særlig opmærksomhed. Tværtimod ser det nu ud til, at det lykkedes for det kinesiske regime at få mange tusinde internationale eliteidrætsfolk og rollemodeller i deres hjemlande til at formidle et positivt indtryk af Kina som verdenspolitisk aktør efter det blændende show i Beijing.

\section{WAR WITHOUT WEAPONS}

Frasen om sportens upolitiskhed er en besværgelse, der har som ypperste formål at hindre, at den olympiske sport trækkes ned på det profane politiske hverdagslivs niveau, hvorved den mister sin magi. For grundlæggeren af det moderne OL i 1896, Pierre de Coubertin, videreførte 
den moderne olympiske atlet nemlig den antikke atlets religiøse gudedyrkelse ved at ære "sit fædreland, sin oprindelse, sit flag«.

Målet var at skabe en ophøjet kult, hvor nationalfølelsen kunne få fuld udfoldelse og nationerne måle sig i fredelig kappestrid, hvorved krigens virkelige styrkeprøve bedre kunne holdes i skak: krig uden våben. Pierre de Coubertin forestillede sig vitterligt, at nationalstaternes bedste sønner gennem en fredelig konfrontation på de olympiske anlæg ville kunne befrugtes af »en religiøs følelse« opnået gennem OL's ritualer og symboler.

Hvert fjerde år skulle menneskeheden genfødes i en forløst, vitaliseret og fællesskabsfølende tilstand. Den olympiske hymne angiver fors $\varnothing$ get på at skabe en sakral stemning. Den blev komponeret specielt til de første moderne olympiske lege i Athen 1896 af Spyros Samaras til et digt af Kostis Palamas: „Udødelige fortidens ånd, fader til det gode, skønne og sande ...«. Dertil kommer faklen, der er blevet tændt i Olympia ved solens stråler, og efter en verdensomspændende rejse nu skal antænde den olympiske flamme på stadion, hvor den skal brænde ubrudt indtil legenes afslutning. Endvidere den olympiske ed, hvor en person fra værtsnationen - altså ved OL 2008 en kinesisk atlet - siger: „På alle deltageres vegne lover jeg, at vi vil deltage $\mathrm{i}$ disse olympiske lege med respekt og lydighed over for de regler, der styrer dem, og i idrættens ånd, så det kan være til ære og hæder for vore hold «.

Blandt andre betydningsbærende punkter er det olympiske motto: Hurtigere-højere-stærkere, ringene i blå-gul-sort-grøn og rød, kanonskud og brevduer, hvilket i øvrigt er en rød klud foran alverdens dyreværnsorganisationer, da duerne flakser forvirrede omkring, og en del af dem risikerer at blive brændt op i den olympiske flam- me. Som afslutning på åbningsceremonien afspilles det arrangerende lands nationalmelodi.

De olympiske leges liturgi er langsomt blevet udviklet gennem legenes historie og er derfor et sammensurium af ritualer. For eksempel blev fakkelløbet introduceret af den tyske organisationskomité under Hitlers olympiske lege i Berlin 1936. Kulminationen ved indmarchen kommer, når værtslandet altså i 2008 det kinesiske hold marcherer ind til allersidst, hvilket vanen tro udløste enorm begejstring blandt de mange kinesiske tilskuere, der var vidne til OL-historiens største hold. Hvis der var truende skyer i horisonten blev de forsøgt skudt væk med kemiske granater, og afslutningsvis tog kinesernes overdådige tradition for fyrværkeri vejret fra os alle, skønt en del af fyrværkeriet var optaget tidligere og nu blev genudsendt. Den lille smukke pige, der sang solo fint, sang i øvrigt slet ikke, men var blevet valgt til at mime, fordi den egentlige sanger skønnedes ikke at være køn nok.

For en nyfødt nation er det at deltage i indmarchen ved OL bag en strunk og stout fanebærer og en skiltebærer med nationens navn den endelige emotionelle inddragelse i nationernes kreds. Men for at markere sig nationalt skal man også helst vinde medaljer eller endnu bedre komme højt på nationernes medaljerangliste, og kineserne har satset alt på at blive nr. 1 denne gang. Allerstærkest kan man dog manifestere sin nationalfølelse og sælge et kulturpolitisk budskab til alverden, hvis man opnår det i dag uhyre eftertragtede at blive olympisk værtsby.

\section{OL SOM KULTURPROPAGANDA}

Til gengæld for at gøre OL til en megaevent med en astronomisk omsætning tildeles værtsbyen og værtslandet af Den Internationale Olympiske Komité en mulighed for ikke mindst gennem åb- 
ningsceremonien at sælge et positivt billede af sin egen kultur og sin styreform til tv-seere over hele verden. Som den største fast tilbagevendende begivenhed i verden er OL og ikke mindst åbningsceremonien fuldstændig ubetalelig set ud fra et reklamesynspunkt, når det gælder om at gøre et land kendt og skabe goodwill om dets image.

Værtslandet får adgang til at politisere gennem at forbinde sig med de olympiske symbolers ophøjethed. For eksempel overtog kineserne helt fakkelløbets stormfulde vej gennem Europa, USA og Korea til IOC's store fortrydelse på grund af profaneringen af det olympiske ritual. Men for kineserne var det vigtigt, at fakkelløbets vej ikke blev brudt, om den så skulle foregå i det skjulte og under massiv politibeskyttelse. Frem for alt skulle faklen gennem Tibet og op på et i øvrigt uvejrsramt Mount Everest for at demonstrere Tibets ubrydelige enhed med Riget i midten trods opstand og undtagelsestilstand. Ved faklens ophold i Lhasa by fremkom den regionale leder af Kinas Kommunistparti Zhang Qingli i øvrigt med følgende såre politiske bemærkning: "Vi vil helt sikkert være i stand til totalt at knuse Dalai Lama-klikens lumske planer «.

Modpolitisering er til gengæld ikke accepteret af IOC, og "sammenblanding af sport og politik« betyder derfor i reglen, at IOC og værtsnationens politikmonopol udfordres. Det udtrykker jo en farlig konkurrence over for IOC's kernevare, som er salg af uovertrufne kanaler for nationalpolitisk selviscenesættelse. Da faklen i Olympia blev overdraget fra den græske til den kinesiske olympiske komité, markerede det, at Kina nu angiveligt var værdig til at varetage de ophøjede olympiske idealer »til gavn for den harmoniske udvikling af mennesket med hen- blik på at fremme oprettelsen af et fredeligt samfund, der er optaget af bevarelsen af den menneskelige værdighed «. Det var jo en betragtelig politisk gevinst for det kinesiske et-partistyre. Da en person fra " Journalister uden grænser« til gengæld protesterede mod denne opfattelse ved på Olympia at løbe ind bag hovedtaleren, præsidenten for den kinesiske organisationskomité, for at vise et flag med de olympiske ringe som håndjern, så blev det af IOC fordømt i stærke vendinger som en "politisk manifestation «. Når en sådan protesthandling vækker så stor vrede i IOC, er det naturligvis fordi, det truer med at trække hele tæppet væk under illusionen om sporten som apolitisk.

\section{ÅBNINGSCEREMONIEN}

For kineserne har åbningsceremonien haft højeste prioritet, arbejdet med de 10.000 medvirkende er pågået i tre år, og der er investeret uendelige summer. Organisationskomiteen havde endog hyret Steven Spielberg til at bruge sin fabelagtige illusionskunst i skabelsen af åbningsceremonien, men han stod af, da det gik op for ham, at den kinesiske statsledelse fortsat støttede det sudanske regime, der udøver folkemord på dets egne indbyggere i Darfur. Til gengæld var en anden verdenskendt filmskaber, Zhang Yimou, der blandt andet står bag mesterværket »Tiger på spring, drage i skjul« hovedinstruktør på højtideligheden, hvilket tydeligt kunne ses især i den fænomenale antændelse af faklen ved den ældre tidligere topatlet, forretningsmanden Li Ning, der i svævende Zhang Yimou-stil bevægede sig på overjordisk vis.

Ceremonien var i øvrigt frem til selve dagen for åbningen omgærdet af en tavshed, som ellers kun var en statshemmelighed værdig, og deltagerne var naturligvis underlagt tavsheds- 
pligt. Det var derfor en stor bet, at det sydkoreanske fjernsynsselskab SBS, nogle dage forinden sendte hemmelige optagelser fra prøverne, og for anden gang siden protesterne mod faklen i Seoul kom Kina og Sydkorea på kollisionskurs.

To af arrangørerne bag showet, Wang Chaoge og Fan Yue, afslørede dog også før premieren, at scener fra Sichuan og Wenchuan vil indgå som en "hyldest til den kinesiske ånd « efter det katastrofale jordskælv i Sichuan-provinsen den 12. maj 2008. Under åbningsceremonien gik den 2,29 meter høje kinesiske basketballstjerne Yao Ming da også hånd $\mathrm{i}$ hånd med en lille pige fra jordskælvet i Sichuan.

De kinesiske myndigheder havde efter en indledende fase, hvor de håndterede katastrofen med stor åbenhed og stort engagement, lukket mere og mere ned over for protester mod, at skoler var bygget så uansvarligt, at de brasede sammen over tusindvis af skoleelevers hoveder, hvorimod regeringskontorer stod uskadte. For en kinesisk påtvungen etbarnsfamilie er den ultimative katastrofe at miste det eneste barn, hvortil alt fremtidshåb er knyttet. Det vil derfor være en kærkommen lejlighed for regimet at demonstrere medfølelse på den ultimative platform, som OL udgør, hvorved enhver forestilling om regimets umenneskelighed og ligegyldighed med det enkelte individ skal bortviskes.

Under åbningsceremonien søgte kameraet i høj grad den kinesiske statsleder $\mathrm{Hu}$ Jintao og den halve snes medlemmer af politibureauets stående udvalg samt udenlandske statsoverhoveder og monarker. I øvrigt mærkeligt, hvis politik og sport ikke har noget med hinanden at gøre, at det kan medføre landekrise, hvis en udenlandsk politisk leder ikke vil møde op. Ud over Hu Jintao og IOC's præsident holdt også præsidenten for den kinesiske organisationsko- mité (BOCOG) tale, så kineserne fik god lejlighed til at markere sig også verbalt over for verdenspublikummet.

Ceremonien spillede i høj grad på den righoldige kinesiske historie og kultur. Målet var at demonstrere, at Kina i dag er langt fra den tidligere opfattelse af "Asiens syge mand «. Herved blev den nuværende magtelite i Beijing fremstillet som blomsten af en tusindårig national kinesisk kulturtradition, og rødderne i maoisme, de katastrofale "store spring fremad" og kulturrevolution flashede bort. Helt i tråd hermed opretter de kinesiske myndigheder overalt $i$ verden i disse år Kungfutse-kulturinstitutter for at betone det nuværende regimes samklang med den oldgamle kinesiske tradition for lydighed og respekt over for alderdommen, foresatte og autoriteter.

Åbningshøjtideligheden spillede også på den rige kinesiske tradition for kampkunst med utallige variationer af kung fu. Her har Kina virkelig bidraget til den internationale idrætskultur. Det lykkedes for Japan at få judo fast på det olympiske program efter OL i Tokyo i 1964 og også for Sydkorea at få Taekwondo fast på programmet efter OL i Seoul 1988. Kineserne har gennem de seneste år sendt delegationer rundt $\mathrm{i}$ verden for at promovere deres wushu i dens moderne form som olympisk disciplin, men det vil næppe lykkes, da den ikke er særligt udbredt som konkurrencesport uden for Kina, og da der dyrkes utallige varianter.

Kineserne har en lang tradition for massekoreografier, der stammer helt fra maoismens tid, hvor iscenesættelser af synkrone, farverige og storsmilende menneskemasser var i høj kurs. Hvor ceremonierne tidligere var meget disciplineret og militaristiske, er der de seneste årtier sket en opblødning med stærk inspiration fra 
vestlig discomusik og med en betoning af kønsforskellen i markant modstrid med den traditionelle maoistiske kønsløshed i form af fælles uniformslignede hverdagstøj. En opblødning, der dog endnu ikke er nået længere end, at den kinesiske censur fortsat nidkært bekæmper tilløb til "pornografi» f.eks. i litteraturen. Denne discoficering viste sig dog ikke i åbningshøjtideligheden, der var mere præget af traditionelle budskaber.

Et af de mere markante politiske budskaber viste sig i øvrigt ved, at det kinesiske militær i strækmarch og med militær præcision stod for op- og nedtagning af det kinesiske og det olympiske flag. I kinesisk sammenhæng er militær tilstedeværelse ved idrætsbegivenheder dog helt normal og ukontroversiel. Ved et indslag med børn, der skulle repræsentere alle Kinas folkeslag, var der i øvrigt kun brugt etniske hankinesere i koreografien.

Alt i alt var åbningsceremonien dog ikke så direkte politisk, som det kunne forventes. Vi har nemlig et meget godt billede af, hvilke politiske og kulturelle budskaber de kinesiske myndigheder sender af sted, når de er eneafsendere af budskaber ved sportsstævner. Generalprøven til OL blev nemlig afholdt for tre år siden i fuld offentlighed i Nanjing i form af "National Games" 2005. En specialeskriver fra Institut for Idræt i København, Christian Enemark, har op til OL i Beijing vist, at åbningsceremonien byggede på en ret uhæmmet politisering med massiv dyrkelse af hæren, af præsident $\mathrm{Hu}$ Jintao (ikke mindst når det tibetanske hold blev vist) og af Kinas rumprogram kulminerende med, at en svævende robot antændte ilden. Der blev også henvist til at ære Hu Jintaos og Deng Xiao Pengs "storslåede teorier".

De kinesiske arrangører turde ikke politisere i en sådan grad, men dyrkelsen af Kina som ypperste eksponent for moderniteten samt enheden i det kinesiske folk fremstod dog klart, og det indgik da også i de officielle kinesiske slogans om »harmoniens OL« og »high tech OL«.

\section{KONKLUSION}

Når mantraet om, at sport og politik ikke har noget med hinanden at gøre, gang på gang fremhæves, skyldes det lige omvendt, at elitesport og politik er intimt forbundet. Det er et sigende vidnesbyrd om, hvor fleksibelt og usubstantielt sloganet om ikke at sammenblande sport og politik egentlig er, at DIFs tidligere formand, det tidligere IOC-medlem Kai Holm, der frem mod OL i 2008 hånede menneskerettighedsaktivister på fakkelruten, var det eneste medlem af DIFs bestyrelse, der ønskede at boykotte legene i Moskva i 1980 med den begrundelse, at de var politiske. Frasen om sportens og politikkens adskilthed er et tomt tegn, som kan bruges til at give en hvilken som helst idrætspolitisk handling et ædelt og neutralt skær. Man gør derfor klogt i at spidse ørerne, når en idrætsleder eller politiker hævder, at sporten er hævet over politikken, for et sådant udsagn er i reglen et skalkeskjul for en stærk politisering af sporten.

IOC-medlemmet Prins Axel kan bruges som et manende eksempel på, hvordan også royale idrætsledere meget nemt kommer til at medvirke til regimers selviscenesættelse. Det er klart, at DIF får utrolig god branding ud af kronprins Frederiks kandidatur til IOC, men mindre soleklart om kongehuset ikke mister noget af sin integritet og sin hæven sig over de politiske vande ved at stikke hånden ind $\mathrm{i}$ den idrætspolitiske hvepserede.

Selvfølgelig fungerer alle OL og især deres åbningsceremonier som en form for kulturpro- 
paganda for værtslandet. På den vis fulgte de teknisk og organisatorisk set uhyre succesfulde Beijing-lege en tradition. Men det er lige så selvfølgeligt noget specielt, at vi har givet en et-partistat med store problemer med menneskerettighederne og med stærke etniske grænsekonflikter ret til at udnytte en åbningsceremoni med et ritualiseret og semireligiøst skær i harmoniens og den mellemfolkelige respekts navn. Det må siges at have krævet virkelig meget af tv-seerens kritiske sans, da »the greatest show on earth" i Beijing gik hen over skærmen. At forskere i sport og politik ikke behøver at blive arbejdsløse lige med det samme, ses af, at IOC har givet Vinter-OL 2014 til den russiske by Sochi, der ligger tæt på Sydossetien i det konfliktplagede Kaukasusområde, hvor vi i 2008 oplevede en georgisk offensiv i ly af OL i Beijing og et brutalt russisk modsvar.

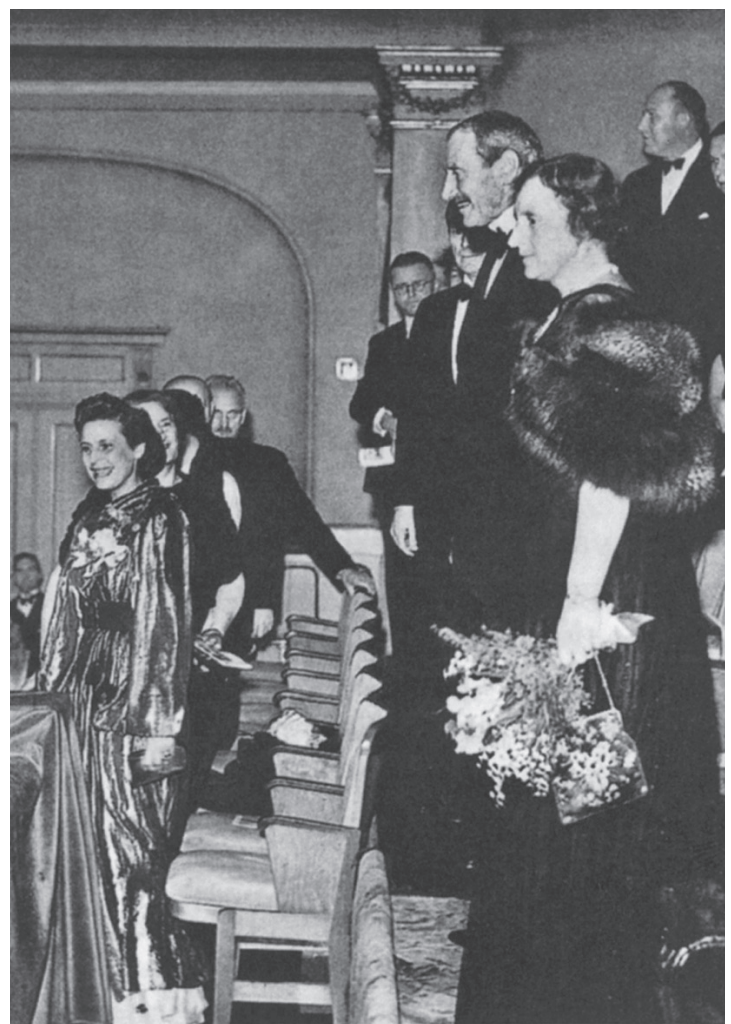

Leni Riefenstahls Olympiafilm forevises i København i august 1938 under overværelse af det danske kongepar (Riefenstahl, 2000, s.311) 


\section{LITTERATUR}

Brownell, S. (2008). Beijings Games - What the Olympics Mean to China. Rowman \& Littlefield Publishers, INC.

Close, P., Askew, D. \& Xin, X. (2007). The Beijing Olympiad - The political Economy of a Sporting Mega-event. Routledge, London and New York.

Guoqi, X (2008). Olympic Dreams, china and sports. Harvard University Press, London.

Heinskou, N.N. (2009). Danmark bliver vært uden stemmeret. Politiken, 12.01.2009. (1.sektion), s. 12 .

Jarvie, G., Hwang, D-J. \& Brennan, M. (2008). Sport revolution and the Beijing Olympics. Berg.

Price, M. \& Dayan, D. (2008). Owning the Olympics - Narratives of the New China. The University og Michigan Press, USA.

Riordan, J. \& Jones, R. (1999). Sport and Physical Education in China. Spon Press, London.

Worden, M. (2008). China's Great Leap - The Beijing Games and Olympian Human Rights Challenges. Seven Stories Press, New York. 